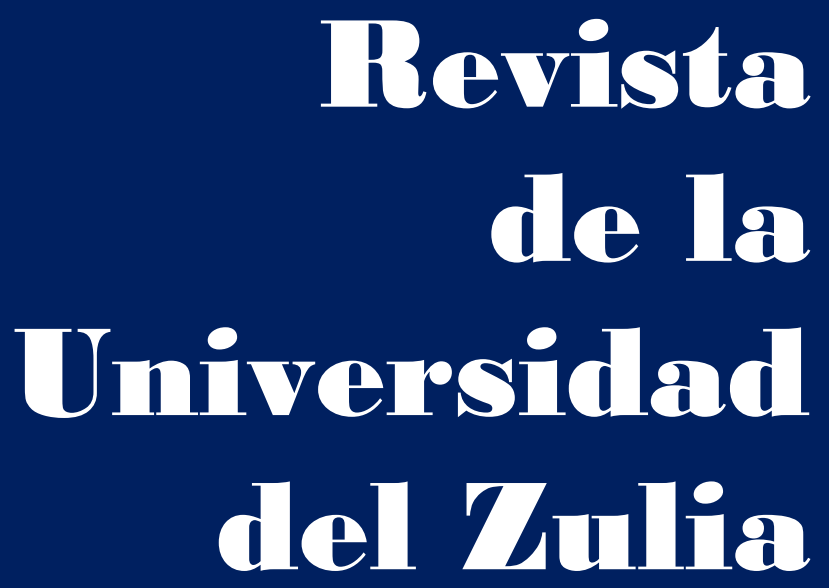

Fundada en 1947

por el Dr. Jesús Enrique Lossada

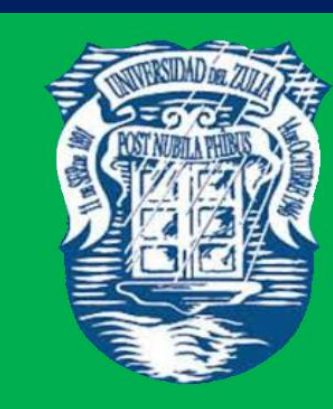

Ciencias del

Agrad,

Ingemiería

y Tecinología

\section{Aกัต 13 No $\mathbf{3 6}$} Enero - Abril 2022

Tercera Épaca

Maracailbo-Venezuela 


\title{
Adjustment of water demand norms for accompanying crops in rice crop rotations
}

\author{
Roman S. Masnyi \\ Sergey M. Vasilyev \\ Georgy T. Balakay \\ Lidiya M. Dokuchayeva \\ Rita Y. Yurkova
}

ABSTRACT

The relevance of the study is due to the need to save water resources. The purpose of study is to determine microclimatic correction factors for monitoring and adjusting the norms of water de-mand for accompanying crops in rice crop rotations for various zones of natural moistening in Russia. The main study methods are experimental (field) and comparative analysis of the data obtained with theoretical calculations. Study results: Correction factors are presented for calcu-lating evapotranspiration / evaporation of accompanying crops in rice crop rotations, varying in the regions of Russia from Ccr $=0.75$ to $C \mathrm{cr}=0.94$, respectively, at from $\mathrm{Cm}$ 0.2-0.3 to $\mathrm{Cm}$ 0.8-1.0 and it is determined that in the rice crop rotation it is necessary to take into account the residual additional productive moisture reserves after rice, which is in the meter soil layer - from $60 \mathrm{~mm}$ in regions with $\mathrm{Cm}=0.2-0.3$ to $84 \mathrm{~mm}$ with $\mathrm{Cm}$ 0.8-0.1. Practical significance: The use of micro-climatic correction factors for adjusting the norms of water demand for accompanying crops makes it possible to calculate and justify the volume of water for irrigation of these crops in rice crop rotations and to save water resources.

KEYWORDS: water; crops, agricultural products, rice; irrigation.

Candidate of Military Sciences, Acting Director of Russian Scientific Research Institute of Land Improvement Problems, Novocherkassk (Rostov region), Russia.

Doctor of Technical Sciences, Professor, First Deputy Director of Science of Russian Scientific Research Institute of Land Improvement Problems, Novocherkassk (Rostov region), Russia.

Doctor of Agricultural Sciences, Professor, Chief Researcher of Russian Scientific Research Institute of Land Improvement Problems, Novocherkassk (Rostov region), Russia.

Candidate of Agricultural Sciences, Leading Researcher of Russian Scientific Research Institute of Land Improvement Problems, Novocherkassk (Rostov region), Russia.

Candidate of Agricultural Sciences, Senior Researcher of Russian Scientific Research Institute of Land Improvement Problems, Novocherkassk (Rostov region), Russia. 


\section{Ajuste de las normas de demanda de agua para cultivos acompañantes en rotaciones de cultivos de arroz}

RESUMEN

La relevancia del estudio se debe a la necesidad de ahorrar recursos hídricos. El propósito del estudio es determinar los factores de corrección microclimáticos para monitorear y ajustar las normas de demanda de agua para los cultivos acompañantes en las rotaciones de cultivos de arroz para varias zonas de humectación natural en Rusia. Los principales métodos de estudio son el experimental (campo) y el análisis comparativo de los datos obtenidos con cálculos teóricos. Resultados del estudio: Se presentan factores de corrección para calcular la evapotranspiración/evaporación de los cultivos acompañantes en las rotaciones de cultivos de arroz, que varían en las regiones de Rusia desde $C c r=0,75$ a Ccr $=0,94$, respectivamente, a $\mathrm{Cm}$ 0,2-0,3 a Cm 0,8-1,0 y se determina que en la rotación de cultivos de arroz es necesario tener en cuenta las reservas de humedad productiva adicional residual después del arroz, que se encuentra en el metro de capa de suelo - de $60 \mathrm{~mm}$ en regiones con $\mathrm{Cm}=0,2-0,3$ a $84 \mathrm{~mm}$ con cm 0,8-0,1. Importancia práctica: El uso de factores de corrección microclimáticos para ajustar las normas de demanda de agua para los cultivos acompañantes permite calcular y justificar el volumen de agua para riego de estos cultivos en las rotaciones de cultivos de arroz y ahorrar recursos hídricos.

PALABRAS CLAVE: agua; cultivos; producto agrícola; arroz; riego.

\section{Introduction}

Rice is one of the most water-intensive agricultural crops, the production of which takes tens of thousands of cubic meters per hectare, therefore, the issues of saving water resources in rice cultivation are relevant all over the world. Saving water resources is possible by various methods: improving irrigation technology (Wu, 2017; Allen, 1998; Belder, 2007; Redwanur, 2014), breeding rice varieties (Victoriano, 2017), organizational measures (Victoriano, 2017; Mom, 2007), etc.

Rational use of water resources in Russia is becoming one of the urgent tasks of irrigated agriculture. One of the ways to save water is the regulation and management of water distribution by substantiating, developing, and approving regional water consumption standards for agricultural crops and water disposal from irrigation systems (Olgarenko, Vasilyev and Balakay, 2019). It is especially relevant for rice irrigation systems, which are the main consumers of water resources, where 20 thousand $\mathrm{m}^{3}$ or more of irrigation water is 
REVISTA DE LA UNIVERSIDAD DEL ZULIA. 3a época. Año $13 \mathrm{~N}^{\circ}$ 36, 2022

Roman S. Masnyi et al. /// Adjustment of water demand norms for accompanying crops ... 126-139

DOI: http://dx.doi.org/10.46925//rdluz.36.09

supplied to each hectare of rice. In rice-growing regions, it is 70-80\% of the volume of water supplied for irrigation. In the existing normative document GOST R 58331.3-2019 regulating water consumption by agricultural crops, there are no norms for the water demand of rice and accompanying crops in rice crop rotations.

At the moment, the specialists of the Federal State Budgetary Scientific Institution " Russian Research Institute of Land Reclamation Problems " have determined an approach to calculating the norms of water demand for rice (Balakay, 2018; Vasilyev, 2018) and have proposed these norms for various agro-climatic zones of Russia, but they have not developed norms for water demand for accompanying crops of rice crop rotation, the adjustment of which will give the possibility of saving water resources for rice irrigation systems up to 15$20 \%$ by regulating the irrigation regime and operational water distribution, taking into account the norms and, accordingly, reducing the norms of water disposal from them. Thus, the purpose of study is to determine the microclimatic correction factors for adjusting the norms of water demand for accompanying crops in rice crop rotations for various zones of natural moistening in Russia.

\section{Materials and methods}

Today there are many methods for determining evaporation (potential evapotranspiration). The calculation models of H.L. Penman, L. Turk, and H.F. Blaney - V.D. Kriddle are the most well-known and widespread abroad. In Russia - A.M. and S.M. Alpatyev, N.N. Ivanov, N.V. Danilchenko's modified formula, etc. (Ilyinskaya, 2001).

To determine the total evaporation (evapotranspiration, water demand) of a specific field $\left(E T_{j}\right)$ with a specific crop « $j »$, it is necessary to have indicators of biological $(\mathrm{Cb})$ and microclimatic (Co) coefficients of water consumption of this crop in dynamics from germination to maturation. The total evaporation is proposed to be determined by the equation (Methodological guidelines ..., 1984):

$$
E T_{j}=E T_{o} \cdot C_{b} \cdot C_{0}
$$

where $E T_{j}$ is the total evaporation (water consumption) of the field, mm.

$E T_{\mathrm{o}}$ is the evaporation from the field, $\mathrm{mm}$.

$C_{b}$ is the bioclimatic coefficient.

$\mathrm{C}_{\mathrm{o}}$ is the microclimatic coefficient. 
The microclimatic coefficient $\left(C_{o}\right)$ considers the change in the microclimate of an agricultural field under the influence of sprinkler irrigation. It depends on the agro-climatic conditions of a particular territory, the size of the irrigated area $S_{\text {ir }}$ and the phase of development of field crops.

However, in rice crop rotations, where rice is irrigated superficially by flooding paddies with rice, the use of the same microclimatic coefficients $\left(C_{0}\right)$ to calculate the evapotranspiration of accompanying crops in rice crop rotations leads to large calculation errors.

To be able to calculate the water demand norms for accompanying crops in rice crop rotations during flooding of rice, studies were carried out and correction microclimatic coefficients for these crops $C_{\mathrm{cr}}$ instead of $C_{\mathrm{o}}$ were obtained. The microclimatic correction factor $C_{\mathrm{cr}}$ differs from the microclimatic coefficient $C_{\mathrm{o}}$ in that it considers the peculiarities of evaporation from the water surface of rice paddies flooded with water and from the fields of irrigated accompanying crops in conditions of rice crop rotations.

$C_{c r}$ is calculated for a certain period as a quotient of the value of evaporation (potential evapotranspiration) of crops from rice crop rotation fields to the evaporation of the same crops in field crop rotations. Calculations of monthly evaporation $E_{o}$ were determined by the formula of N. N. Ivanov (Norms of water demand ..., 2000):

$$
E_{0}=0,0018 \cdot(t+25)^{2} \cdot(100-\alpha)
$$

where $t$ is the average monthly temperature, ${ }^{\circ} \mathrm{C}$. $\alpha$ is the relative humidity of the air, $\%$.

To establish the indicator $C_{c r}$, instrumental measurements of meteorological parameters were carried out during the growing season of rice for the PetrovskoAnastasievskaya rice irrigation system of the Krasnodar Territory in five replications. The measurements were carried out using the appropriate equipment, starting from the border of the rice irrigation system from the windward side and with further deepening into the rice system itself in the direction of the wind at various distances - from 200 to $7000 \mathrm{~m}$. The processing of the obtained data was carried out using mathematical analysis of the experiment and mathematical statistics. 
REVISTA DE LA UNIVERSIDAD DEL ZULIA. $3^{a}$ época. Año $13 \mathrm{~N}^{\circ}$ 36, 2022

Roman S. Masnyi et al. /// Adjustment of water demand norms for accompanying crops ... 126-139

DOI: http://dx.doi.org/10.46925//rdluz.36.09

Since it was not possible to conduct such field studies for various agro-climatic conditions in Russia, theoretical calculations of these coefficients were carried out using the analog method for all zones with natural moistening $C_{m}$ from 0.2 to 1.0 using the meteorological indicators of meteorological stations of specific territories.

\section{Results}

Analysis of experimental data in rice crop rotations allowed us to establish indicators of changes in microclimatic coefficients $C_{c r}$ during the growing season of various accompanying crops, associated with increased relative moisture in rice crop rotations and, as a consequence, lower air temperature. In this regard, the correction factor $C_{c r}$ also changes during the growing season of crops. For example, the calculations showed that in the Petrovsko-Anastasievskaya rice irrigation system of the Krasnodar Territory in April (on average) $C_{c r}$ was 0.94 , and in July - 0.72 (Table l).

Table 1. Evaporation $E_{0}$ in rice and field crop rotations and microclimatic correction coefficient $C_{c r}$ during the growing season of crops.

\begin{tabular}{|c|c|c|c|c|c|c|c|}
\hline \multirow[t]{2}{*}{ Month } & \multicolumn{3}{|c|}{ In rice crop rotations } & \multicolumn{3}{|c|}{ In field crop rotations } & \multirow[t]{2}{*}{$C_{c r}$} \\
\hline & $\mathrm{T}^{\circ} \mathrm{C}$ & $\alpha, \%$ & $E_{0}, \mathrm{~mm}$ & $\mathrm{~T}^{\circ} \mathrm{C}$ & $\alpha, \%$ & $E_{0}$ & \\
\hline 1 & 2 & 3 & 4 & 5 & 6 & 7 & 8 \\
\hline \multicolumn{8}{|c|}{ Experimental data } \\
\hline April & 12.5 & 63.8 & 91.6 & 13.0 & 62.4 & 97.7 & 0.94 \\
\hline May & 18.5 & 61.8 & 130.1 & 19.5 & 59.8 & 143.3 & 0.91 \\
\hline June & 24.4 & 63.4 & 160.7 & 24.0 & 52.4 & 205.7 & 0.78 \\
\hline July & 28.3 & 65.1 & 177.8 & 29.0 & 53.2 & 227.5 & 0.72 \\
\hline August & 25.4 & 44.2 & 255.0 & 26.4 & 35.4 & 307.2 & 0.83 \\
\hline Average & 21.6 & 59 & 177.7 & 21.4 & 49 & 205.0 & 0.84 \\
\hline \multicolumn{8}{|c|}{ Theoretical calculations } \\
\hline \multirow[t]{2}{*}{ Month } & \multicolumn{3}{|c|}{$\begin{array}{l}\text { According to the archival data of } \\
\text { the meteorological station of the } \\
\text { city of Slavyansk-on-Kuban }\end{array}$} & \multicolumn{3}{|c|}{$\begin{array}{l}\text { According to the archival data of } \\
\text { the meteorological station of the } \\
\text { city of Timashevsk }\end{array}$} & \multirow{2}{*}{$K_{p r}$} \\
\hline & $\mathrm{T}^{\circ} \mathrm{C}$ & $\alpha, \%$ & $E_{0}$ & $\mathrm{~T}^{\circ} \mathrm{C}$ & $\alpha, \%$ & $E_{0}$ & \\
\hline April & 11.5 & 68.9 & 74.6 & 12.0 & 67 & 81.3 & 0.92 \\
\hline May & 17 & 72.1 & 88.6 & 18.4 & 69 & 105.1 & 0.84 \\
\hline June & 22.3 & 69.0 & 124.8 & 23.1 & 62 & 158.3 & 0.79 \\
\hline July & 25.1 & 64.0 & 162.6 & 25.7 & 54 & 212.8 & 0.76 \\
\hline August & 26 & 57.0 & 201.3 & 26.1 & 49.8 & 238.9 & 0.85 \\
\hline Average & 20.3 & 66.2 & 130.4 & 21.1 & 60.3 & 158.7 & 0.83 \\
\hline
\end{tabular}


REVISTA DE LA UNIVERSIDAD DEL ZULIA. 3a época. Año $13 \mathrm{~N}^{\circ}$ 36, 2022

Roman S. Masnyi et al. /// Adjustment of water demand norms for accompanying crops ... 126-139

DOI: http://dx.doi.org/10.46925//rdluz.36.09

Figure 1 shows the relationship between the correction factors established by theoretical calculations and experimental data using meteorological parameters.

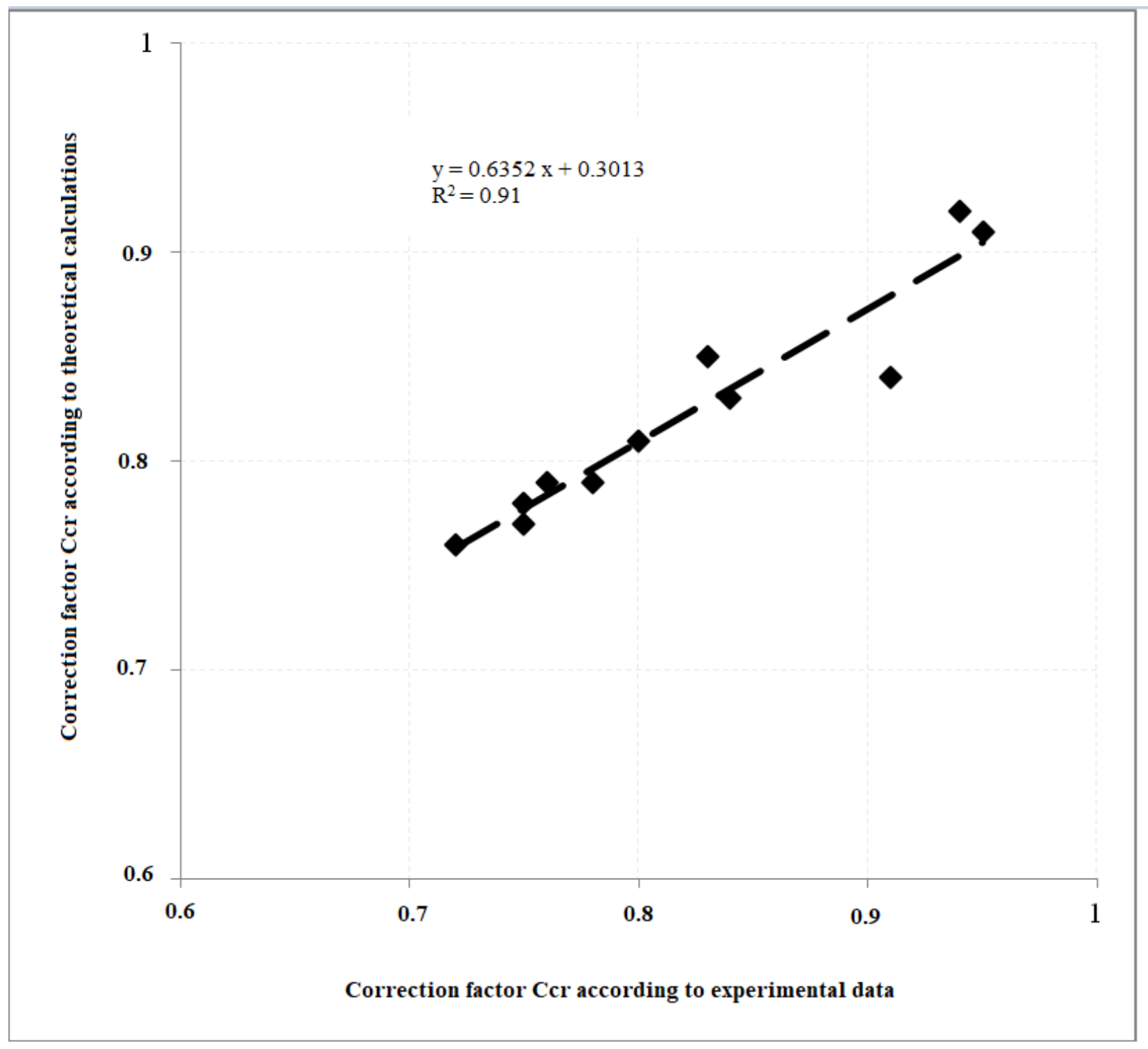

Figure 1. Relationship between correction factors obtained from experimental and theoretical data

The resulting relationship equation $y=0.6352 \mathrm{x}+0.3013$ and the approximation coefficient $\mathrm{R}^{2}=0.91$ confirm the reliable convergence of the microclimatic correction coefficients obtained during instrumental field studies of changes in temperature, air humidity and wind speed directly on rice and field crop rotations, as well as correction factors, calculated using the same meteorological parameters, but taken from the archive of meteorological stations in Slavyansk-on-Kuban and Tinashe's of the Krasnodar Territory (electronic resource). 
REVISTA DE LA UNIVERSIDAD DEL ZULIA. $3^{a}$ época. Año $13 \mathrm{~N}^{\circ}$ 36, 2022

Roman S. Masnyi et al. /// Adjustment of water demand norms for accompanying crops ... 126-139

DOI: http://dx.doi.org/10.46925//rdluz.36.09

The close relationship of the obtained microclimatic correction coefficients made it possible by the same analogy method to calculate the microclimatic correction coefficients for accompanying crops cultivated in rice crop rotations for different moistening zones using data from meteorological stations in rice-growing regions with observation periods of at least 35 years (Table 2 ).

Table 2. Data of $C_{c r}$ obtained by calculation method for various natural moistening zones

\begin{tabular}{|l|c|c|}
\hline \multicolumn{1}{|c|}{ Region } & Moistening coefficient $C_{m}$ & Microclimatic correction factor $C_{c r}$ \\
\hline Astrakhan region & $0.2-0.3$ & 0.75 \\
\hline Republic of Kalmykia & $0.2-0.3$ & 0.75 \\
\hline Republic of Dagestan & $0.3-0.4$ & 0.81 \\
\hline \multirow{2}{*}{ Rostov region } & $0.3-0.4$ & 0.81 \\
\hline \multirow{2}{*}{ Krasnodar Region } & $0.4-0.5$ & 0.83 \\
\hline Primorsky Krai & $0.45-0.5$ & 0.83 \\
\cline { 2 - 3 } & $0.5-0.6$ & 0.85 \\
\hline
\end{tabular}

The reliability of the microclimatic correction factors obtained by the calculation method for various moistening zones is confirmed by the close relationship between $C_{c r}$ and $\mathrm{C}_{m}$ (Figure 2). The approximation coefficient was 0.87 , which indicates a close relationship between these indicators.

In addition, a close relationship ( $\mathrm{R} 2=87$ ) has been established between the coefficients of natural moistening content $\mathrm{Cm}$ and the relative correction factors to the norm of water demand of accompanying crops Crel.cr, equal to (l-Ccr), if we accept the condition that at $\mathrm{Cm}=1$ there will be a balance between evaporation and precipitation (Figure 3).

Figure 3 shows that the drier the climate, the more water evaporates from flooded paddies (the temperature decreases and the relative humidity of the air increases) and thus this is more reflected in the evaporation and irrigation regime of associated crops, i.e., evapotranspiration and, accordingly, the irrigation rate decreases.

When adjusting the water requirements for accompanying crops in rice crop rotations, additional moisture reserves remaining in the soil after rice cultivation should be considered. As studies carried out in Kalmykia have shown, residual moisture reserves in the spring period are quite large and, regardless of weather conditions in the autumn-winter period, the meter layer contained water from 74.3 to $88 \%$ of field moisture capacity and more (Balakay, 2017; Consolidated norms ..., 2013; Kravchenko, 2007). 
REVISTA DE LA UNIVERSIDAD DEL ZULIA. 3a época. Año $13 \mathrm{~N}^{\circ}$ 36, 2022

Roman S. Masnyi et al. /// Adjustment of water demand norms for accompanying crops ... 126-139

DOI: http://dx.doi.org/10.46925//rdluz.36.09

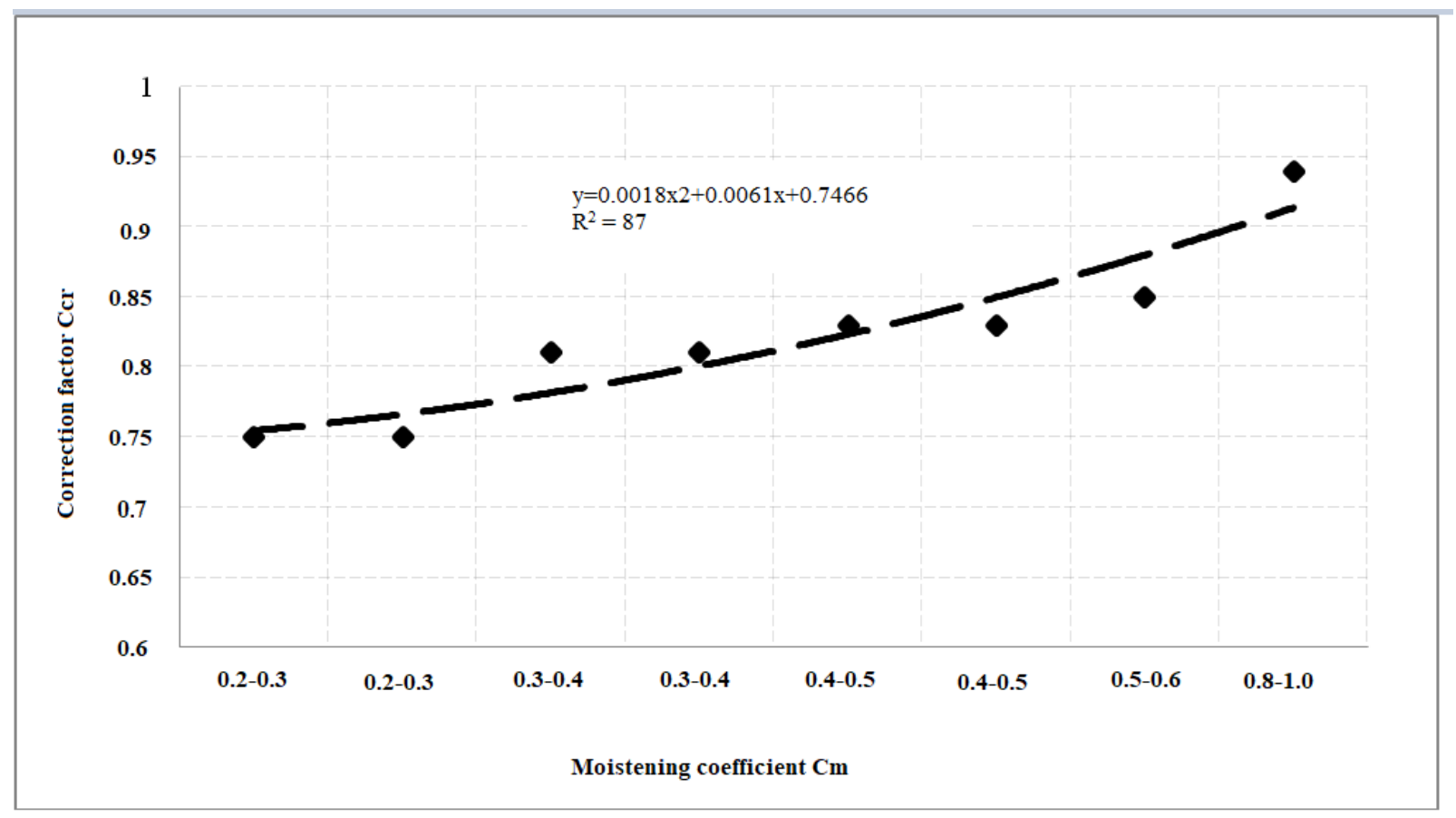

Figure 2. Relationship between microclimatic correction factors and moistening factors for different agro-climatic zones

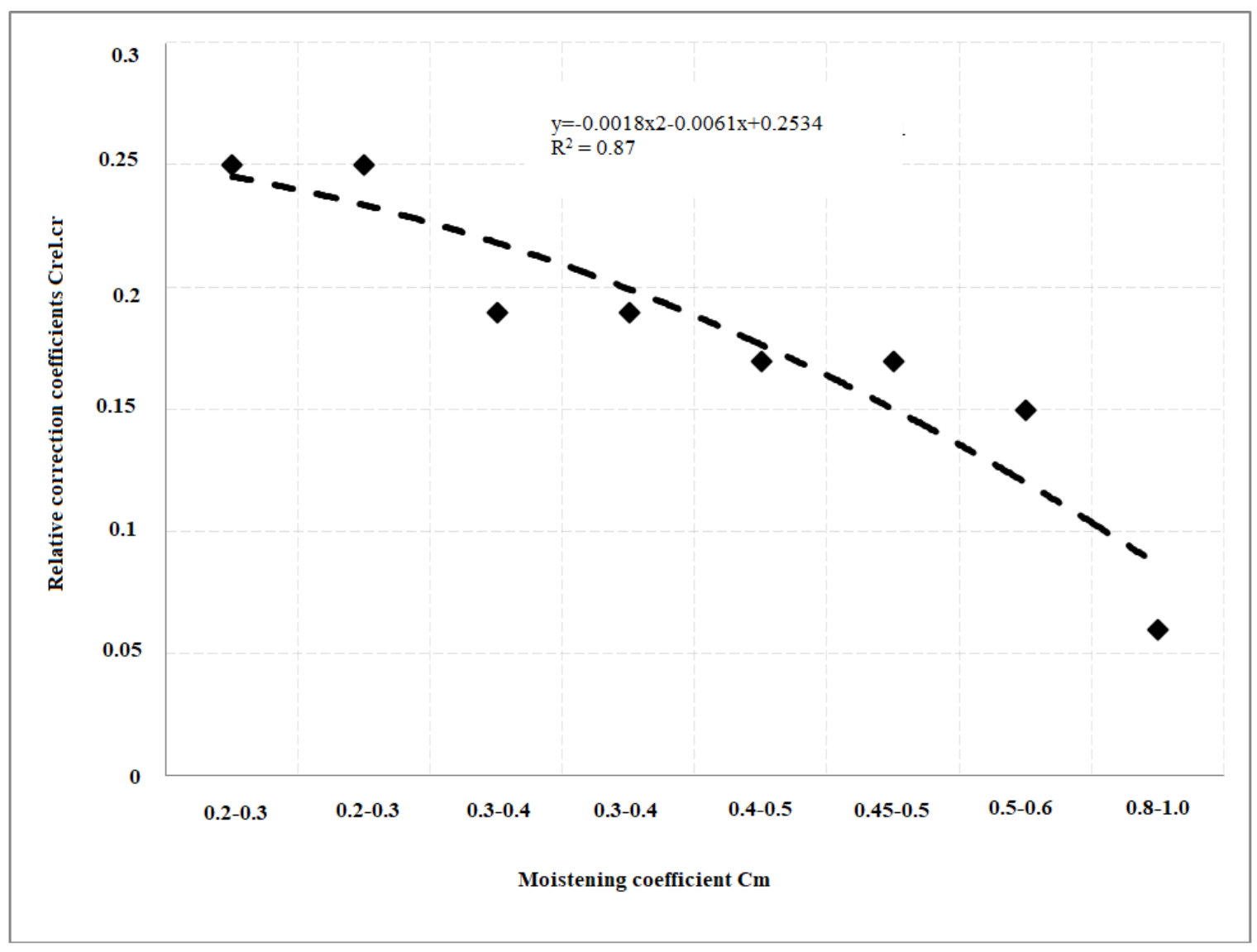

Figure 3. Relationship between natural moisture factors $C_{m}$ and relative correction coefficients $C_{\text {rel.cr }}$ 
REVISTA DE LA UNIVERSIDAD DEL ZULIA. $3^{a}$ época. Año $13 \mathrm{~N}^{\circ}$ 36, 2022

Roman S. Masnyi et al. /// Adjustment of water demand norms for accompanying crops ... 126-139

DOI: http://dx.doi.org/10.46925//rdluz.36.09

We also carried out studies to establish residual moisture reserves in the soil of paddies in the spring before sowing accompanying crops (Table 3).

Table 3. Moisture and moisture reserves in a meter layer of soil before sowing in paddies after rice cultivation

$(\mathrm{n}=5)$

\begin{tabular}{|c|c|c|c|c|c|c|c|c|}
\hline \multirow{2}{*}{$\begin{array}{l}\text { Layer, } \\
\mathrm{cm}\end{array}$} & \multicolumn{7}{|c|}{ Moisture } & \multirow[b]{2}{*}{$\begin{array}{l}\text { Moisture } \\
\text { reserves } \\
\text { at the } \\
\text { beginning } \\
\text { of the } \\
\text { growing } \\
\text { season, } \\
\text { mm }\end{array}$} \\
\hline & $\begin{array}{l}\text { Actual, } \% \\
\text { abs. dry soil }\end{array}$ & $\delta, \%$ & $\mathrm{~V}, \%$ & $\begin{array}{l}\text { Field } \\
\text { moisture } \\
\text { capacity, } \\
\%\end{array}$ & $\delta, \%$ & $\mathrm{~V}, \%$ & $\begin{array}{l}\text { Actual, } \% \\
\text { from field } \\
\text { moisture } \\
\text { capacity }\end{array}$ & \\
\hline 1 & 2 & 3 & 4 & 5 & 6 & 7 & 8 & 9 \\
\hline \multicolumn{9}{|c|}{ Nizhne-Manychskaya irrigation system, Rostov region $C_{m}=0.31-0.4$} \\
\hline $0-20$ & 21.2 & 0.68 & 3.2 & 26.5 & 1.10 & 4.3 & 80 & 58.9 \\
\hline $20-40$ & 19.1 & 0.71 & 3.7 & 24.5 & 0.95 & 3.9 & 78 & 53.4 \\
\hline $40-60$ & 20.1 & 0.83 & 4.3 & 24.5 & 1.07 & 4.4 & 82 & 56.5 \\
\hline $60-80$ & 22.3 & 0.74 & 3.1 & 26.5 & 0.95 & 3.6 & 84 & 62.5 \\
\hline $80-100$ & 23.8 & 0.69 & 2.9 & 27.6 & 0.86 & 3.1 & 86 & 66.7 \\
\hline $0-100$ & 21.3 & 0.73 & 3.4 & 26.0 & 0.99 & 3.9 & 82 & 298.0 \\
\hline
\end{tabular}

Petrovsko-Anastasievskaya rice irrigation system, Krasnodar Territory, $C_{m}=0.45-0.50$

Continuation of table 3

\begin{tabular}{|l|c|c|c|c|c|c|c|c|}
\hline \multicolumn{1}{|c|}{1} & 2 & 3 & 4 & 5 & 6 & 7 & 8 & 9 \\
\hline $0-20$ & 22.9 & 0.85 & 3.7 & 28.3 & 1.25 & 4.4 & 81 & 64.3 \\
\hline $20-40$ & 22.5 & 0.90 & 4.0 & 28.9 & 1.18 & 4.1 & 78 & 63.2 \\
\hline $40-60$ & 22.8 & 0.96 & 4.2 & 28.8 & 1.35 & 4.7 & 79 & 64.1 \\
\hline $60-80$ & 25.4 & 1.29 & 5.1 & 31.7 & 1.61 & 5.1 & 80 & 71.6 \\
\hline $80-100$ & 26.9 & 1.05 & 3.9 & 32.8 & 1.24 & 3.8 & 82 & 74.8 \\
\hline $0-100$ & 24.1 & 1.01 & 4.2 & 30.1 & 1.32 & 4.4 & 80 & 338.0 \\
\hline
\end{tabular}

Note $\delta$ is the standard deviation, $\mathrm{V}$ is the coefficient of variation.

The results showed that under the conditions of the Rostov region in the zone with $C_{m}=0.31-0.40$ on soils with a heavy loamy composition, these moisture reserves in the meter layer amounted to $298 \mathrm{~mm}$ or $82 \%$ of field moisture capacity, and on clay soils of the Krasnodar Territory in the zone with $C_{m}=0.45-0.50$, respectively, $338 \mathrm{~mm}$ or $80 \%$ of field moisture capacity. At the same time, the calculations of the standard deviation and the coefficient of variation indicate insignificant variability of moisture and moisture reserves in the soil in the spring after rice in different regions. 
REVISTA DE LA UNIVERSIDAD DEL ZULIA. $3^{a}$ época. Año $13 \mathrm{~N}^{\circ}$ 36, 2022

Roman S. Masnyi et al. /// Adjustment of water demand norms for accompanying crops ... 126-139

DOI: http://dx.doi.org/10.46925//rdluz.36.09

The data obtained allow us to assert that in the spring of the next year, after the cultivation of rice, the moisture in the soil remains equal in volume to at least $80 \%$ of field moisture capacity. Based on this, for the main rice-sowing regions, we calculated the residual moisture reserves after rice cultivation before sowing accompanying crops, considering the properties of soils and data of field moisture capacity (Table 4). They ranged from $238 \mathrm{~mm}$ in the Astrakhan region to $325 \mathrm{~mm}$ in the Primorsky Krai.

Table 4. Residual moisture reserves after rice cultivation

\begin{tabular}{|l|c|c|c|c|c|c|c|}
\hline \multicolumn{1}{|c|}{ Region } & $\mathrm{C}_{\mathrm{cr}}$ & $\begin{array}{c}\text { Soil by } \\
\text { granulometric } \\
\text { composition }\end{array}$ & $\begin{array}{c}\text { Field } \\
\text { moisture } \\
\text { capacity } \\
\text { \% abs. } \\
\text { dry soil }\end{array}$ & $\begin{array}{c}\text { Moisture } \\
\text { reserves } \\
\text { at field } \\
\text { moisture } \\
\text { capacity, } \\
\text { mm }\end{array}$ & $\begin{array}{c}\text { Moisture } \\
\text { reserves at } \\
\text { the } \\
\text { beginning of } \\
\text { the growing } \\
\text { season, mm }\end{array}$ & $\begin{array}{c}\text { Productive } \\
\text { moisture, } \\
\mathrm{mm}\end{array}$ & $\begin{array}{c}\text { Residual } \\
\text { moisture } \\
\text { reserves, } \\
\text { mm }\end{array}$ \\
\hline $\begin{array}{l}\text { Astrakhan } \\
\text { region }\end{array}$ & $\begin{array}{c}0.21- \\
0.30\end{array}$ & Medium loamy & 22 & 297 & 238 & 178 & 60 \\
\hline $\begin{array}{l}\text { Republic of } \\
\text { Kalmykia }\end{array}$ & $\begin{array}{c}0.21- \\
0.30\end{array}$ & Medium loamy & 23 & 308 & 246 & 185 & 61 \\
\hline $\begin{array}{l}\text { Republic of } \\
\text { Dagestan }\end{array}$ & $\begin{array}{c}0.31- \\
0.40\end{array}$ & Heavy loamy & 25 & 340 & 272 & 204 & 68 \\
\hline Rostov region & $\begin{array}{c}0.31- \\
0.40\end{array}$ & Heavy loamy & 26 & 364 & 298 & 218 & 66 \\
\cline { 2 - 9 } & $0.41-$ & Loamy & 30 & 414 & 331 & 248 & 83 \\
\hline $\begin{array}{l}\text { Krasnodar } \\
\text { Region }\end{array}$ & $\begin{array}{c}0.45- \\
0.50\end{array}$ & Loamy & 30 & 423 & 338 & 254 & 84 \\
\cline { 2 - 9 } & $0.50-$ & Heavy loamy & 27 & 367 & 294 & 220 & 74 \\
\hline $\begin{array}{l}\text { Primorsky } \\
\text { Krai }\end{array}$ & 0.60 & Loamy & 29 & 406 & 325 & 244 & 81 \\
\hline
\end{tabular}

Moisture should remain in the soil at the level of productive reserves of at least $60 \%$, while the share of residual moisture in the total volume of moisture reserves after rice for accompanying crops ranges from 60 to $84 \mathrm{~mm}$ or $32-33 \%$.

\section{Discussions}

For 40 years, the Southern Scientific Research Institute of Hydraulic Engineering and Melioration (Russian Research Institute of Land Reclamation Problems), together with other institutes (All-Russian Scientific Research Institute "Raduga", Central Scientific Research Institute for the Integrated Use of Water Resources), have been studying irrigation 
REVISTA DE LA UNIVERSIDAD DEL ZULIA. $3^{a}$ época. Año $13 \mathrm{~N}^{\circ}$ 36, 2022 Roman S. Masnyi et al. /// Adjustment of water demand norms for accompanying crops ... 126-139 DOI: http://dx.doi.org/10.46925//rdluz.36.09

regimes for agricultural crops by sprinkling in field crop rotations, creating mathematical models for calculating productive moisture reserves for various types soil and in various agroclimatic conditions of Russia, which made it possible not only to develop standards for the water demand of field crops, but also to promptly adjust irrigation regimes according to meteorological parameters, taking into account the agro-climatic conditions of a particular irrigated area (Water demand norms ..., 2000; Ilyinskaya, 2001; Methodological guidelines ..., 1984; Calculation of irrigation regimes ..., 2012; Balakay, 2017).

Based on the data of long-term field studies, the norms of water demand for crops were calculated and regulated depending on the heat and moisture supply of the year according to the integrated indicator $C_{m}$ - the coefficient of natural moisture in a particular area and provision the year according to the indicator of the water balance deficit (Enlarged norms ..., 2013). Heat and moisture supply of the year was characterized by meteorological parameters: average daily precipitation, temperature, relative air humidity and wind speed. When using office, mathematical and statistical processing of field studies, patterns, dependencies, relationships were established, which made it possible to obtain bioclimatic and microclimatic coefficients, calculate the water demand of plants and develop a regulatory document for the main field crops GOST R 58331.3-2019 - Water demand for irrigation of agricultural crops. However, such studies of the total evaporation of these field crops as accompanying crops under the conditions of rice crop rotations have not been carried out.

The concept of this calculation is based on the fact that moisture evaporation from permanently flooded rice paddies occurs more intensively than from crops of field irrigated crop rotations, where sprinkler irrigation is carried out two to eight times per season and high soil and plant moisture and, accordingly, more evaporation is observed only in the first two or three days after watering. It should be noted that with different irrigation methods on rice systems and in field crop rotations, the main indicators of the microclimate (temperature and relative humidity) change in different ways, which have a significant effect on the evapotranspiration / evaporation rates of plants, this must be considered and appropriate corrections must be made by introducing correction coefficients into the calculation methodology.

It should also be noted that water resources are saved in rice crop rotations due to the use of residual moisture reserves in the soil by accompanying crops that go in the crop 
REVISTA DE LA UNIVERSIDAD DEL ZULIA. $3^{a}$ época. Año $13 \mathrm{~N}^{\circ}$ 36, 2022 Roman S. Masnyi et al. /// Adjustment of water demand norms for accompanying crops ... 126-139 DOI: http://dx.doi.org/10.46925//rdluz.36.09

rotation fields after rice. Residual (after rice) moisture reserves of productive moisture in the soil are highly stable and vary for a layer of $1 \mathrm{~m}$ from 155 to $189 \mathrm{~mm}$ (Kravchenko, 2007). For example, in the first year of life of alfalfa in the total water consumption, residual moisture reserves after rice amounted to $41 \%$ (Smykov, 2005). In Kalmykia, resource-saving technologies, for cultivating dry crops capable of generating high yields without watering due to the use of moisture reserves remaining after rice, are being introduced on rice systems (Melikhov, 2016, Dubenok, 2014; Rakitina, 2017).

Conclusion

Evaporation of moisture from constantly flooded rice paddies occurs more intensively than in crops of field crop rotations irrigated by sprinkler irrigation, where the number of irrigations per season is from two to eight, and high moisture content of soil and plant tissues and, accordingly, greater evaporation is observed only in the first two to three days after watering. In rice crop rotations with flooded paddies, evaporation increases and, accordingly, the microclimate changes, including temperature decrease and relative humidity increase, which have the major effect on plant evapotranspiration.

On the basis of experimental and theoretical studies, correction factors were obtained for calculating evapotranspiration / evaporation of accompanying crops in rice crop rotations, varying in the regions of Russia from $C_{\mathrm{cr}}=0.75$ to $C_{\mathrm{cr}}=0.94$, respectively, at $\mathrm{C}_{\mathrm{m}}$ from 0.2-0.3 to $C_{m} 0,8-1.0$.

The natural relationship has been established between the correction factors obtained between the experimental data and the theoretical ones, calculated from the meteorological parameters of meteorological stations in the regions, expressed by an equation of the form $y$ $=0.6352 x+0.3013$ with an approximation coefficient $R^{2}=0.91$.

When calculating the norms of water demand for accompanying crops, it is necessary to consider the residual additional productive moisture reserves in the meter layer of soil from $60 \mathrm{~mm}$ in regions with $C_{\mathrm{m}}=0.2-0.3$ to $84 \mathrm{~mm}$ - with $\mathrm{Cm}$ 0.8-0.1.

\section{References}

Allen, R. G., Pereira, L. S., Raes, D., Smith, M. (1998). Crop evapotranspiration - Guidelines for computing crop water requirements. FAO Irrigation and drainage. 56 p., Rome (Italy): FAO. https://appgeodb.nancy.inra.fr/biljou/pdf/Allen FAOl998.pdf. 
REVISTA DE LA UNIVERSIDAD DEL ZULIA. $3^{a}$ época. Año $13 \mathrm{~N}^{\circ}$ 36, 2022 Roman S. Masnyi et al. /// Adjustment of water demand norms for accompanying crops ... 126-139

DOI: http://dx.doi.org/10.46925//rdluz.36.09

Balakay, G.T., Dokuchayeva, L.M., Yurkova, R.E. (2018). On the issue of developing norms of rice water demand and water disposal from rice irrigation systems. Scientific Journal of the Russian Research Institute of Problems of Land Reclamation, 3(31), 1-22. http://www.rosniipm-sm.ru/dl_files/udb_files/udbl3-rec557-field6.pdf. _ - DOI: 10.31774/2222-1816-2018-3-1-22.

Balakay, G.T., Balakay, N.I. (2017) Methodology for calculating and adjusting the timing of irrigation of agricultural crops. Scientific journal of the Russian Research Institute of Problems of Land Reclamation, 1 (25), 32-49. www.rosniipm-sm.ru/dl files/udb files/udbl3rec461-field6.pdf.

Belder, P., Bouman, B. A. M., Spiertz, J. H. J., Lu, G. (2007). Exploring options for water savings in lowland rice using a modelling approach. Agricultural Systems 92, 91-114. https://www.sciencedirect.com/science/article/pii/S0308521X06000382.

Calculation of irrigation regimes for agricultural crops and design standards for water demand: methodological recommendations: under edition of G.V. Olgarenko (2012). Kolomna: Inlight LLC. -151 p.

Consolidated norms of water demand for irrigation of agricultural crops in the Central, Volga, Ural, Siberian, South and North Caucasian federal districts (2013). http://mcxdm.ru/sites/all/files/normi vodopotrebnosti.pdf.

Dubenok, N.N., Kuznetsova, V.V., Borodychev, V.V., Adyaev, S.B. (2014) Spring barley is a promising crop of rice crop rotations in Kalmykia. Bulletin of the Nizhnevolzhsky agrouniversity complex, 1 (33). https:/cyberleninka.ru/article/v/yarovoy-yachmenperspektivnaya-kultura-risovyh-sevooborotov-kalmykii.

GOST R 58331.3-2019. Reclamation systems and structures. Water demand for irrigation of agricultural crops. General requirements. - Introduction. 2019-03-15. - M.: Standartinform, 2019. $-25 \mathrm{p}$.

Hydraulic and optimization calculations of main and distribution canals of different order of the irrigation system ("RasChet.canal"): certificate of Federal Institute of Industrial Property for the state registration of computer software / V.N. Shchedrin [and others], 2014619417 dated of 16.09.14; declared of 31.07.14, 2014617618, 9 p.

Ilyinskaya, I.N. (2001). Rationing of water demand for irrigation of agricultural crops in the North Caucasus: monograph. Novocherkassk: South Russian State Technical University, 164 p.

Kravchenko, A.V. (2007). Substantiation of technological methods of cultivation of soybeans in rice crop rotation: abstract dissertation of the candidate of agricultural sciences. Volgograd. https://dlib.rsl.ru/viewer/01003056960\$2?page=1.

Md. Redwanur, R., Sheikh, H. B. (2014). Effect of Alternate Wetting and Drying (AWD) Irrigation for Boro Rice Cultivation in Bangladesh. Agriculture, Forestry and Fisheries, 3, 86-92. http://www.sciencepublishinggroup.com/journal/paperinfo?journalid=119\&epaperId=600447 $\underline{1}$. 
Melikhov, V.V., Popov, A.V., Dedova, E.B., Dedov, A.A. (2016). Cultivation of dyeing safflower in the rice crop rotation of the Sarpinskaya lowland. Bulletin of the Nizhnevolzhsky agrouniversity complex. 3 (43). https://cyberleninka.ru/article/n/vozdely-vanie-saflorakrasilnogo-v-risovom-sevooborote-sarpinskoy-nizmennosti.

Methodological guidelines for the creation of system of norms for water demand and water disposal in irrigated agriculture (1984). Minsk: Central Research Institute for the Integrated Use of Water Resources. 129 p.

Mom, R. (2007). A high spatial resolution analysis of the water footprint of global rice consumption. mom.rjc@gmail.com, https:/www.utwente.nl/en/et/wem/education/mscthesis/2007/mom.pdf.

Norms of water demand and environmentally safe irrigation regimes for agricultural crops: recommendations (2000). Edited by A.V. Kolganov, V.N. Shchedrin, Southern Research Institute of Hydraulic Engineering and Land Reclamation. - M.: Meliovodinform. - 152 p.

Olgarenko, G.V., Vasilyev, S.M., Balakay, G.T. (2019). The concept of the State program "Restoration and development of the reclamation complex of the Russian Federation for the period 2020-2030". Novocherkassk: Russian Research Institute of Land Reclamation Problems, $128 \mathrm{p}$.

Rakitina, N.V., Borodychev V.V., Adyaev, S.B. (2013). Sugar sorghum is a promising crop of rice crop rotation. Bulletin of the Nizhnevolzhsky agro-university complex, 1 (29). https://cyberleninka.ru/article/n/saharnoe-sorgo-perspektivnaya-kultura-risovogosevooborota.

Smykov, A.V. (2005). Influence of alfalfa on the meliorative state of brown semi-desert soil and rice yield in the Sarpinskaya lowland: abstract dissertation of the candidate of agricultural sciences: Saratov, 2005 http://earthpapers.net/vliyanie-lyutserny-nameliorativnoe-sostoyanie-buroy-polupustynnoy-pochvy-i-urozhaynost-risa-v-sarpinskoynizmennosti-1.

Vasilyev, S.M., Balakay, G.T., Dokuchayeva, L.M., Yurkova, R.E., Gonzalez-Gallego, M.R., Netseplyaev, D.A. (2018). Computer software 2018666607. Calculation of the norms of water demand for rice and norms of water disposal from the rice field, 2018663851; declared of 03.12.18; published of 19.12.18.

Victoriano, J. P., Wang, Y. M. (2017). Impact of Water Management on Rice Varieties, Yield, and Water Productivity under the System of Rice Intensification in Southern Taiwan. Water, 9(1), 3. https://www.mdpi.com/2073-4441/9/1/3/htm.

Wu, X. H., Wang, W., Yin, C. M., Hou, H. J., Xie, K. J., Xie, X. L. (2017). Water consumption, grain yield, and water productivity in response to field water management in double rice systems in China. Plos one. https://journals.plos.org/plosone/article?id=10.1371/journal.pone.0189280 